\title{
1. Diaspora networks in international business: a review on an emerging stream of research
}

\author{
Maria Elo
}

\section{INTRODUCTION}

Migration creates diaspora. For example, immigration accounted for 40 percent of total population growth in the Organisation for Economic Co-operation and Development area between 2001 and 2011 (OECD, 2013, p. 14). Diasporans are migrants and their descendants who maintain a relationship to their country of origin (Safran, 1991). The concept of diaspora originated from Greek history and Jewish studies, but it later spread to a number of disciplines. There is a vast diaspora-related literature, for example, in history, sociology, ethnology, and public administration.

On the other hand, very little research has been conducted on the role of diaspora in business. Diaspora venturing and their international business (IB) activities are rather unknown. Furthermore, the way they facilitate development and business by transferring knowledge, innovation, and goods is only partially discovered, and the inter- and intra-diaspora business and entrepreneurial dynamics represent a challenge, not to mention the role of diaspora networks in the shadow economy. The increase in global migration provides numerous challenges to research and policy making (Cohen, 2008). For example, there is very little work on 'entrepreneurial migration' (Çavuşgil et al., 2011, p. 591). On the other hand, an increasing number of studies have discovered how diasporans establish companies and invest, how they network for international trade, and how their diasporic nature creates clusters and development. For example, Brinkerhoff (2009) provides evidence for the role of diaspora in bridging markets and creating business.

In general, the stream of research on diaspora in business is very fragmented and often located in disciplinary silos. This review attempts to provide an overview to key areas of research by focusing on business and economic issues. Its purpose is to increase the understanding of the role and influence of diaspora networks in IB and entrepreneurship. 


\subsection{Defining the Concept of Diaspora}

Diaspora as a phenomenon has been studied in a number of disciplines, and therefore, it is not surprising that the definitions used vary and generate criticism (Safran, 1991; Usher, 2005). This is naturally a challenge for researchers because creating common ground for collaboration and understanding of the phenomenon is difficult. Additionally, the variety of interpretations creates confusion and ambiguity. From the viewpoint of a state-of-the-art review, it is essential that the focal phenomenon is explicitly defined. Thus, this chapter defines diaspora as the phenomenon that describes migrants and their descendants (diasporans) who maintain a relationship to their country of origin (Safran, 1991). This interpretation is in line with Usher (2005, p.47) who considers diasporas to be 'transnational populations living in a country other than their country of origin, but with ties to the country of origin'. These ties can be both sentimental and material (Sheffer, 1986), and they demonstrate themselves in multiple ways, including a collective memory, even idealization about the homeland, collective commitment to its development and prosperity, and strong ethnic group consciousness with empathy and solidarity with other co-ethnic members (Cohen, 2008). The ties may be strengthened by creation of, and involvement in, diaspora associations or organizations (Brinkerhoff, 2009). However, diaspora identity is not unequivocal as it is a complex evolving state and not a static concept. The identity has a hybrid nature, 'it lives with and through the difference' (Hall, 1990, p. 235), as it is constantly produced and reproduced; thus, there can be no fixed perception (Brinkerhoff, 2009).

It should be noted that although 'diasporan' is not an ontologically identical term to 'immigrant', the two terms are often used as synonyms. 'Migration' and 'migrant' are terms employed in global and national statistics of cross-border human flows (also called 'permanent inflows'; OECD, 2013), whereas diaspora involves additional dimensions of human life. Although in principle the terms describe the same phenomenon, the difference is in the psychic link that the diasporans maintain with their homeland (Gillespie et al., 1999). Whereas immigrants integrate in their host country and are typically not bound to each other (de Lange, 2013), diasporans are migrants who settle in some places, move on, and regroup; they may also be dispersed, but in any case as a group they 'are in a continuous state of formation and reformation' (Cohen, 2008, p. 141). Given the overlap between the concepts, they are applied interchangeably in this chapter, and the review also includes studies that apply other related terms, such as 'emigrant', 'immigrant', 'ethnic', or 'migrant'. However, the inherent ontological differences of the terms are acknowledged, hence 
the limitations and deficits related to these differences remain inherent in this review.

Diaspora networks are social formations, also referred to as selforganized groups of expatriates (Kuznetsov, 2006). Diaspora networks are but the latest bridge connecting developing economy insiders, with their risk-mitigating knowledge and connections, to outsiders in command of technical know-how and investment capital (Kuznetsov, 2006). As Dutia (2012, p.4) notes, diaspora networks are also evolving entities: 'In today's context, the size of Diaspora networks and the global reach that they extend due to inexpensive air travel and communications channels are re-defining their potential. At one point, Diasporas were internationally dispersed networks, but now they have evolved and have become structured and more interdependent than ever before'.

\subsection{Problem Setting and Focus of the Study}

The global mobilization of diaspora networks and their potential have not yet attracted much interest in the IB research despite the impact of the phenomenon. Cohen (2008) introduces four key aspects with particular bearings on the international mobilization of diasporas: a globalized economy, new forms of international migration, the development of cosmopolitan sensibilities, and the revival of religion as a focus for social cohesion. Currently, outside IB there is a pool of various institutions and disciplines that all address the phenomenon from their particular perspectives. Owing to these organizational and focal boundaries, there is very little holistic understanding of what forms this phenomenon of diaspora takes in the global economy and how it works. Inter-disciplinary and multidisciplinary overviews explaining diaspora networks are lacking.

Therefore, the study applies network lenses and asks what kind of research findings have been discovered so far, in particular: what are the influences of diaspora in the globalized economy, what forms do they take, and are particular mechanisms identified? It explores the scope of research areas and identifies central findings on the forms and roles of diaspora networks and their mechanisms. Its objective is to illuminate major aspects of the economic dimension of diaspora networks. The review concentrates on providing an overview of the key research areas that have evolved around the aspect of globalized economy and presenting extant findings.

The importance of diaspora networks has multiple levels. As Frannie A. Léautier, Vice President of the World Bank Institute notes, 'Actors in Diaspora networks can be crucial bridges between global state-of-the-art in policy, technological, and managerial expertise and local conditions in their home countries' (World Bank, 2006). 


\subsection{Research Approach and Structure of the Study}

A state-of-the-art review combines the advantages of rich research on this interdisciplinary topic and the focal choice of the globalized economy (see Malhotra et al., 1996; Srivastava, 2007). Owing to its nature, diaspora research has an overwhelming presence in other disciplines, such as sociology, anthropology, history, and cultural studies. The focus on globalized economy-relatedness delimits the scope of the analysis. The central interest is on the contemporary research of the new millennium.

The review itself is built on two combined approaches (see EasterbySmith et al., 2002). First, an inductive interest guided reading process on journal articles, books, research reports, and newspaper articles took place to provide a broad view and understanding of the phenomenon studied. Numerous in-depth discussions with scholars, experts, and diaspora businesses were carried out between 2011 and 2014 to reflect their views on the current knowledge and to identify elements of high importance and international relevance. The collected written material and the discussions were not limited to IB, but represented numerous disciplines. A significant purpose of these discussions was to identify issues of importance from various perspectives to avoid theory bias. Thus, an interdisciplinary reflection on the topic took place to enhance the quality of the approach.

Second, a more systematic investigation of diaspora research articles in the IB context was carried out using scientific journal databases and diaspora/diaspora network as keywords. The electronic library NELLI system was used to collect all relevant articles available at ScienceDirect published 2005-13. The academic journals selected as relevant were: Journal of International Management, International Business Review, Journal of Business Research, Journal of World Business, Business Horizons, Scandinavian Journal of Management, Journal of Economic Behavior \& Organization, and European Management Journal. Altogether, the search generated 61 articles. The top five publishers (49 articles) of articles were: Journal of International Management (15), International Business Review (12), Journal of Business Research (9), Journal of World Business (8), and Business Horizons (5). After the identification of these 61 articles, the titles, abstracts, keywords, and the introductions were assessed against the topic of diaspora networks in IB and the relevance of the article was categorized as highly relevant, relevant, or irrelevant. The irrelevant articles were excluded. The highly relevant and relevant articles have been included in accordance with their contribution in understanding diaspora networks in IB, they totaled 15 articles.

The concrete review steps were taken accordingly (see Srivastava, 2007): (1) defining the focus: diaspora and diaspora networks in B; 


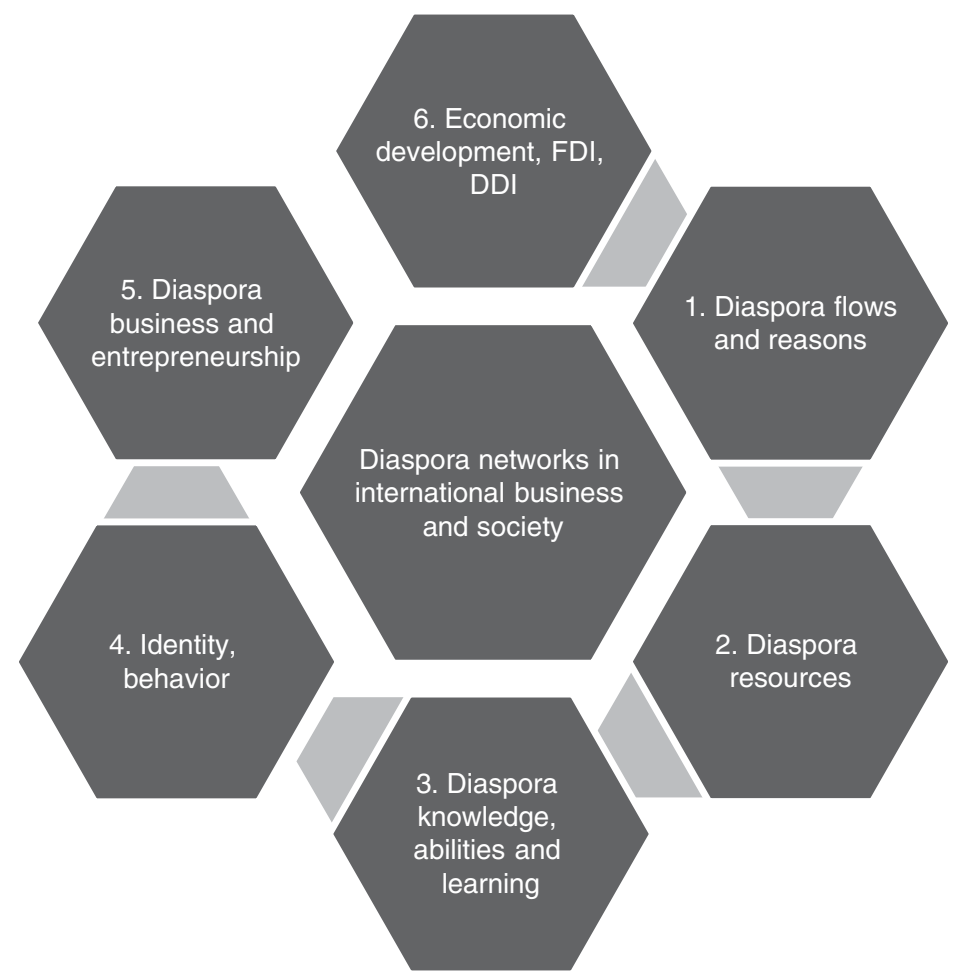

Figure 1.1 Diaspora-related themes in international business

(2) classification of context: diaspora effect/element and IB setting, classified into six categories in Figure 1.1; (3) collecting publications: inductive search and academic journal search; (4) material evaluation comprising identification of relevance and content, and organization of contents into classification schema.

This study analyzes the recent development of the diaspora network literature following an IB perspective. First, the introduction briefly presents the concepts diaspora and diaspora networks and connects them to the economy and IB. Second, the review identifies the diaspora-related themes that are significant in IB-related literature. Based on these themes identified in the literature, the chapter is organized into six review sections, which are classified in Figure 1.1. The study ends with a discussion and conclusion, which presents key findings, implications, and suggestions for further research.

The findings indicate that diaspora networks have had significant 
effects on numerous elements of IB: on country-level competitiveness; capital, labor, and human resource-development; creation of clusters, ethnic economies and businesses; import and export, knowledge and resources transfer and sharing; identity and behavioral development toward transnationalism; diaspora entrepreneurship; and last, but not least, economic/regional development, foreign direct investment (FDI), and diaspora direct investment (DDI). In addition, the reviewed studies provide a multitude of additional lenses to apply in understanding diaspora networks' role in IB.

The review contributes to increasing the understanding of the economic aspects of diaspora networks, in particular, in the context of IB.

\section{AN OVER VIEW OF DIASPORA NETWORKS IN INTERNATIONAL BUSINESS AND SOCIETY}

\subsection{Diaspora Flows and Reasons behind Them}

International migration is shaping the modern economy and society as it concentrates in specific demographic attractive regions and metropolitan agglomerations of the developed countries (for example, Aliaga-Isla and Rialp, 2013; Waldinger, 1989). Diaspora and migration studies build strongly on the dichotomy of sending and receiving. This is due to the historical dominance of migration flows from poor to rich countries, or from developing and emerging countries to developed countries. The transnational, multidirectional, and circular views have only started to emerge relatively recently (for example, Levitt, 2001; Riddle et al., 2010).

The migration phenomenon is increasing diachronically; simultaneously its flows are converging (see Figure 1.2). 'Traditional immigration' countries are those that have had a relatively constant inflow of migrants throughout the second half of the twentieth century. They include Australia, Austria, Belgium, Canada, France, Germany, Luxembourg, the Netherlands, New Zealand, Sweden, Switzerland, the United Kingdom, and the United States. 'Traditional emigration' countries are those whose populations tended to emigrate elsewhere throughout the second half of the twentieth century. They include the Czech Republic, Denmark, Finland, Greece, Hungary, Iceland, Ireland, Italy, Japan, Norway, Poland, Portugal, the Slovak Republic, and Spain (OECD, 2009).

Commonly, sending countries represent developing countries or countries that suffer from poverty, political turmoil, lack of perspectives and freedom, unemployment, corruption and institutional obstacles, or other significant push factors for migration. Receiving countries represent 


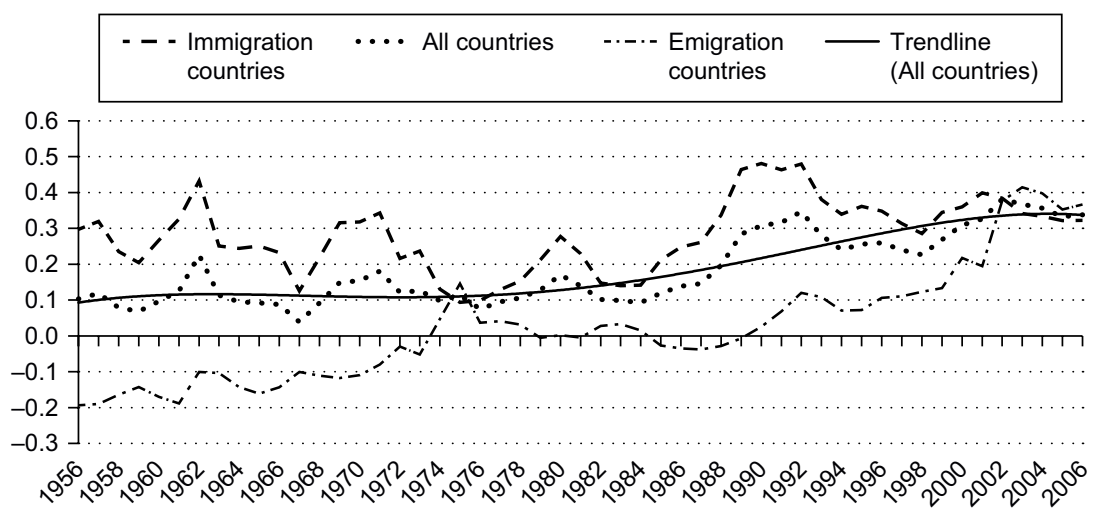

Source: OECD (2009).

\section{Figure 1.2 Increasing and converging migration rates, annual net migration rate of traditional immigration and emigration OECD countries, 1956-2006}

countries of opportunities, often developed countries such as the US. As can be seen, the traditions evolve over time. Concerning country constellations, both Norway and Finland are receiving countries today. Meanwhile, countries such as Greece and Spain have had significant 'immigration' phases that were reversed by the economic downturn starting in 2009. As Flisi and Murat (2011) note, Europe has been both a sending and receiving area, where the flows are tightly connected to history, and even today the economic influences of diaspora are linked to history and are country specific.

Push and pull forces are considered the reasons that regulate the flows of migration. Bevelander and Irastorza (2014, p. 17) found four categories of entry reasons: labor, family, refugee, and student. We recognize that the migration motivation for people leaving a developed country is usually not based on refugee-like reasons, poverty, lack of opportunity, or other negative push factors. Still, there are significant numbers of people involved in diasporic flows between developed and developed countries. In general, diaspora research assumes that people migrate for better opportunities, improved circumstances, economic benefit, or reasons such as better education systems for their children. These diaspora flows from developed to developed countries may be partially explained by such positive pull factors from the new countries of residence (CORs). Family ties are a category of high importance as a driver and change agent in diaspora (Elo and Jokela, 2014; Leinonen, 2012; OECD, 2014). 
Five categories of permanent-type international migration can be identified:

- Work-related - persons admitted for employment on a permanenttype basis, including with a temporary permit that can in principle be renewed indefinitely.

- Free movement - nationals moving within a free mobility zone (for example, European Union/Europe Free Trade Association (EU/ EFTA); Trans-Tasman agreement), except students and temporary mobility (for example, seasonal labor mobility); in general it refers to nationals from other countries in the free-mobility zone (other than students) who stay for more than a year.

- Accompanying family of workers - persons accompanying a principle migrant admitted for work-related reasons (see above).

- Family migration - persons admitted for family reunification and family formation purposes.

- Humanitarian - persons admitted for international protection and other humanitarian reasons, including their accompanying family.

- Other - includes ancestry-based migration, retirees, persons of independent means, and so on.

According to the OECD (2009), all of these categories can include status changes of people already residing in the country under a different, but temporary category (for example, international students changing status after their studies to take on employment in the host country or because they married a national). It is also to be acknowledged that individuallevel migration can be driven by more than one reason. Talib et al. (2012) review and study flows of diasporas and their networks, and discuss their effects on the country level through clusters and their economic consequences.

\subsection{Diaspora Resources}

Diaspora resources are mainly conceptualized as 'transferrable brains', either as brain drain or gain (Wescott and Brinkerhoff, 2006) depending on the perspective, and recently also as circulating resources (McLaughlin et al., 2011). McLaughlin et al. (2011, p.54) point out that the onedirectional approach is too limited. They provide considerations for other models of approaching diaspora resources to better integrate the positive effects of the 'triple win scenario' and circularity, both temporal and more permanent. Globalization, the lowering of immigration and emigration barriers to the movement of people, and the emerging concept 
of boundary-less careers have all contributed to the phenomenon of brain circulation, also called 'triangular human talent flow' (Tung, 2008, p. 299). Carr et al. (2005) do not accept the term 'brain drain' as it is too restrictive; instead they focus on the psychology of migration, specifically the economic, political, cultural, family, and career forces that motivate migration. Wescott and Brinkerhoff's (2006) study illustrates how brain drain functions as the overseas potential pool that can also be employed for the development and business of countries of origin (COOs). Tung (2008) illustrates the positive effect of brain circulation on a country's international competiveness, in line with Chand's (2010) findings. Usher (2005) states that the pool of talent living overseas is playing an increasing role in developing business opportunities and public services in a large number of countries. As an example, she takes India's software industry where 19 of the top 20 software businesses were founded by, or are managed by, professionals from Indian diasporas. For new ideas, new technologies, and new markets, the industry relies on diaspora-led professional organizations in India and abroad, and diaspora-led subsidiaries in key markets such as the US. Professional networks, skills matching initiatives, community initiatives, FDI, and lobbying and advocacy represent new methods of diaspora engagement. There are four factors that influence the brain circulation and refer to respective policies: (1) industrial arrangement in home and host countries, (2) trust, learning, and entrepreneurship, (3) the status of financial infrastructure for start-ups, and (4) the role of the state (Talib et al., 2012, pp. 240-41).

The importance of talent and skills is related to several elements such as integration, employment, performance, but also to transfer of skills and generation of income and remittances (Brinkerhoff, 2006). In their study on immigrant entrepreneurs in the Valencian community, Carbonell et al. (2011) found that the influence of education was crucial as the majority of aspects of business activity depended on it. Lewin and Zhong (2013) explain how the migration of highly skilled workers (such as scientists and engineers) has become a political issue of 'brain drain' that touches the flow from developing to developed countries and its implications, and how a system of global sourcing has emerged to obtain talent, complemented by the shift of organizations becoming mobile workplaces. Hart and Acs (2011) illustrate the significant impact of high-technology immigrant entrepreneurship in the US from the receiver perspective. The role of 'brain' (that is, talent, competence, skills) is often interpreted in relation to education, and is perceived as an instrument for transferring positive effects, such as technology, development, and innovation.

Low-skilled labor diaspora has a long history (see Cohen, 2008), but even today low-skilled labor diasporans are vital as employees for many 
industries and businesses despite the labor market obstacles that many low-skilled and refugee migrants and diasporans encounter in their host countries (for example, Bevelander and Irastorza, 2014). Gender, route of entry and country, region of origin, education level, and sector influence the trends for labor market integration. For example, low education level seemed to have a strong influence on employment and labor-market competitiveness in Sweden where only half of low-educated migrants were employed after 14 years of residence in 2011 (Bevelander and Irastorza, 2014). However, there were employment variations in different cohorts and time-related factors that also influenced the integration.

It is also important to consider the impact of non-categorized irregular migration, which is an employed resource despite its illegal nature. Irregular immigrants (Dugan and Edelstein, 2013) form important labor resources despite their problematic status and they are often subjects of interest for illegal economic activity such as counterfeit distribution and sales (see Cucinotta, 2010). Oliveri (2013) presents a labor case of irregular farmworkers from Italy that illustrates well the systemic relevance of these grey zones of labor. Carbonell et al. (2011) also discuss the importance of immigration restrictions having consequences in promoting illegal immigration. In their conclusions, they refer to the high level of training, education, and knowledge of a country, which is considered to correlate with higher restrictions. In short, the diaspora resources are not limited to 'brain' but also involve a significant and globally flexible labor force, which is combined with their economic impact as citizens and consumers.

Diasporans act as consumers and citizens; they purchase daily goods, invest, and take part in economic life. Thus, they form an economic resource and possess purchasing power. Physical ethnic markets emerge in locations where the accumulation of migrants takes place, but communities may also develop virtual dimensions (see Brinkerhoff, 2009; Hepp et al., 2011). As Saxenian's seminal work on Silicon Valley indicates, diasporas foster the evolution of clusters, drive internationalization, and facilitate the growth of production networks (Sonderegger and Täube, 2010). Diasporas tend to concentrate on attractive metropolitan areas or diasporic enclaves as places of residence owing to a variety of sociocultural and economic reasons. Although it is important to note that different diaspora populations and waves of diaspora are heterogeneous and act differently, diasporans often select locations in the country of origin according to their social capital and the business networks available in the target area (see Sonderegger and Täube, 2010). They are also strongly influenced by their socio-cultural and family ties (Elo and Jokela, 2014). Similar types of drivers affect their location choices in the country of residence (for example, Bergsten and Choi, 2003). Diasporans as employees 
and managers influence the internationalization of firms and their foreign location choice and performance (Hernandez, 2014). Hernandez (2014) suggests that the common country bonds of immigrants can become unique channels of knowledge, providing firms with idiosyncratic benefits in foreign places, which was supported by his study on foreign subsidiaries in the US from 27 countries. His study also indicated that this effect on operations and survival is valid when the concentration of immigrants is of the same nationality, and that the effect is particularly strong for firms lacking prior experience in the country (Hernandez, 2014). Location is also related to time and history: strong historical immigration ties between host and home country increase foreign subsidiary sales, and foreign venture capital firms are more likely to choose a location in states that possess significant immigrant concentrations (Hernandez, 2014, p. 77). Thus, locational choices relate not only to country-level factors, but also to factors related to ethnic economy, socio-cultural dimensions, and entrepreneurship.

\subsection{Diaspora Knowledge, Abilities, and Learning}

Diaspora knowledge is a well-recognized type of knowledge, which often has a central role in the interaction of diaspora communities (see Cohen, 2008) and in the development of COOs. Diaspora knowledge relates not only to the immigrant effect (Chung and Tung, 2013) and the different position of diasporans to view and perceive things, but also to issues related to cultural heritage and social mechanisms. Diaspora knowledge is being possessed, transferred, developed, and redefined in various contexts of business and social life, and it can also become a kind of membership benefit within a certain context (see Brinkerhoff, 2009). Hernandez's (2014) study indicates that connections to co-national immigrants positively influence a firm's location choice and survival through processes of local learning and knowledge transfer in the context of internationalization. However, he criticizes the lack of studies that explore the knowledge implications and the lack of research on the related mechanisms. Social networks and social capital trigger innovation and transfer knowledge, technology, remittances, and resources.

Diaspora knowledge also benefits the host country. Scheffran et al. (2012) studied climate adaptation in the area of Western Sahel and found that diasporic social capital and knowledge that connect home and host countries increase flexibility, diversity, and creativity, and assist in the adaption process. Diasporans are a source of new knowledge, they form knowledge pools and facilitate knowledge spillover, and they and their networks may foster the innovation process (Harikkala, 2013). Harikkala 
(2013) also found that host country stance and policies have a major impact on the ability of the host country to benefit from diaspora knowledge. Diaspora knowledge incorporates a vast potential of synergy and understanding for business (Harikkala, 2013). Vissak and Zhang (2014) illustrated how the networks and inherent knowledge assisted in the internationalization process of their Chinese cases.

The shared understanding provided by diaspora resources is related to socio-cultural issues and informal institutions, but moreover, its importance in terms of communication ability and language skills has been acknowledged (for example, Brinkerhoff, 2009; Hepp et al., 2011). The multiple cultural embeddedness of diaspora involves country-related advantages (see Gillespie et al., 1999; Levitt, 2001), which may also facilitate learning and action in a third-party context, that is, have multidirectional effects (see Talib et al., 2012). Vissak and Zhang (2014) illustrate how diaspora knowledge disseminates innovation via entrepreneurial activity. Aliaga-Isla and Rialp (2012) described how diaspora connections influence entrepreneurship as antecedents conveying information and knowledge. Such diaspora networks have characteristics and functions similar to those of business networks (for example Ford, 2002) as they form channels and pools of knowledge and learning. Riddle and Brinkerhoff (2011) provide an example with their Thamel-case that illustrates how knowledge transfer can take multiple forms, such as communication platforms and learning tools, going beyond the expected scope.

Diaspora-related knowledge provides advantages for marketing. Kumar and Steenkamp (2013) investigated some companies that have followed emigrants from their homelands, concentrating on countries that host them in sizable numbers. They note that the United States has 32 million Mexican-Americans; Germany, 4 million residents of Turkish descent; and the UK, 3 million South Asians, and point out that although not all the members of a diaspora warm to companies or brands from home, emerging giants must identify those who are likely to be receptive. However, those who are receptive can form target groups that act as springboards for growing revenue and gaining brand recognition before breaking into the mainstream. Thus, the effect of diaspora extends beyond ethnic markets and learning may take place multidirectionally.

\subsection{Diaspora Identity and Economic Behavior}

Diasporas are seen as shaping economic landscapes and influencing the systemic level by reducing the difference, as de Lange (2013, p. 14) notes: 'A diaspora, explicated as one that is organized toward political action, becomes embedded in a core host, uses the host's influence to reduce 
state class differences, builds a status-equalizing intercultural channel, and induces an agenda for its homeland'. The difference also relates to the concept of Diaspora identity, which is in a state of flux (Hannerz, 1997); hence, identity reflections on economic behavior follow that development (for example, Cohen, 2008). Numerous scholars have dealt with diasporic identity and its development, especially its flows, boundaries, meanings, and hybridism that evolve over time (Brinkerhoff, 2009; Hannerz, 1997; Tölölyan, 1996). Diaporans and migrants often have different behavioral patterns than the indigenous population, these behavioral patterns may be shared with intra- or inter-diaspora networks. Hart (2011) points out a central aspect of importance related to migrants regarding their entrepreneurship in the USA, he notes that foreign-born founders are more likely to team up with 'other outsiders' like women and US minorities. His study indicates that the effect of homophily is stronger the greater the cultural distance between the entrepreneur's country of origin and the US (Hart, 2011). He also proposes that coethnicity and marriage ties help to bridge the cross-national cultural gap in team formation.

Behavior is not homogenous in diaspora. Behavior is also regulated by prior emotions related to COO. In addition, the assumed sharing of knowledge by individuals is strongly influenced by affect, and thus, partially invalid (Barnard and Pendock, 2013). Diasporas are social entities consisting of a heterogeneous set of people. Transnational diasporans are tangled in a complex system of practices, behavioral patterns, psychological frameworks, and socio-cultural institutions (for example, Vertovec, 2004). This complexity makes it difficult to govern or estimate diaspora behavior and reactions, especially if there is no in-group cohesion and homogeneity.

Research on diaspora and migration is mostly confined to a certain context such as the receiving country (see Hernandez, 2014) or country of origin (see Bergsten and Choi, 2003), or the respective flows and their direction (see Wescott and Brinkerhoff, 2006), but the transnational dimension of diaspora and its interaction architecture have received very little attention (Hernandez, 2014). Migrants may hold ties beyond home and host countries, and in various 'spaces', thus, they have transnational characteristics (for example, Riddle et al., 2010). Tölölyan (1996) removes the conceptual focus from the nation-state thinking when analyzing diaspora and pinpoints the significance of the socio-temporal dimension instead. Transnationalism is a state of being, as Levitt (2001, p. 197) describes, 'those who live within transnational social fields are exposed to a set of social expectations, cultural values, and patterns of human interaction that are shaped by more than one social, economic, and political 
system'. The conception of transnationalism is approached differently in different disciplines (for example, Hannerz, 1997; Vertovec, 1999, 2004).

Cross-cultural entrepreneurial competences are vital in identifying IB opportunities (Muzychenko, 2008). The act of identifying and perceiving opportunities is related to the psychological framework, which consists of developing conscious interest and sensitivity, subconsciously and intuitively considering options, conscious awareness of the new concept, analyzing the viability of insights and their value, and actualization of the creative insight (Lumpkin and Dess, 2001). Muzychenko (2008) proposes that the cross-cultural competence possessed by the entrepreneur, (1) may facilitate the application of competences developed in the home cultural environment within the host country environment, and (2) may improve the entrepreneur's perception of their own capability to identify IB opportunities, and thus, results in a better performance. Then, Muzychenko concludes that cross-cultural competence in identifying opportunities may moderate a contextual interjection of culture by closing competence gaps and increasing the level of IB opportunities and the subsequent effectiveness (Muzychenko, 2008, p. 373). Her conclusion applies to the effect that has been called the immigrant effect (for example, Chung and Tung, 2013; Gillespie et al., 1999).

\subsection{Diaspora Business and Entrepreneurship}

Diasporans carry a negative connotation. This is because they have lost their territories, been confined to particular occupations, and been endogamous in respect of dietary prohibitions, religious practices, and social intercourse, but these perspectives stem more from historical research (see Cohen, 2008). The business-related diasporas that acted as 'middlemen minorit[ies]', such as Jews, Indians, Chinese, Lebanese, and Greeks, have been approached differently due to the trade diaspora character (Cohen, 2008). Bergsten and Choi (2003) provide examples of the Korean diaspora that also involve macro-political forces such as Stalin's population relocations. In the era of globalization, the classic forms - Victim, Imperial, Labor, and Trade diaspora (Cohen, 1997) - have become new dimensions of globalism, digitalism, mediation, and transnationalism (Brinkerhoff, 2009; Cohen, 2008; Hepp et al., 2011). Interestingly, the German KfW bank calls the era 'Neue Gruenderzeit', since diasporans are significantly more active in establishing companies, they are younger than the non-diasporic establishers, and they employ more employees from the beginning. Twenty-one percent of start-ups in Germany are established by diasporans (Metzger, 2014).

However, diaspora business and entrepreneurial effort is not only 
positive and legal. Diaspora networks can also be connected to transnational organized crime (TOC) and distort legal trade and business. For example, Gillespie and McBride (2013) studied how Chinese transnational crime employed the Korean diaspora in the distribution and smuggling of counterfeits into Mexico. Their empirical findings suggest that criminal diaspora enterprises possess certain characteristics that are more similar to those of multinational corporations (MNCs), some characteristics that are more similar to those of legitimate diaspora investors (also called diaspora direct investment), and unique characteristics different from both MNCs and legitimate diaspora investors. In general, the concepts of necessity and livelihood have been central in many studies (for example, Cohen, 2008; Metzger, 2014).

As the problems related to defining diaspora indicate, the complexity of the conceptual landscape continues in definitions related to diaspora business and entrepreneurship.

Diasporas facilitate IB in various ways and on many levels. Diasporans may influence institutional dimensions of business (Riddle et al., 2010), but the majority of the extant research concentrates on the industry, business market, and company-level dynamics. The visibility of influence is well demonstrated in this more meso- and micro-level research. Riddle and Brinkerhoff (2011) provide an example of a business established by a diasporan who successfully interconnects $\mathrm{COO}$ and $\mathrm{COR}$ and develops ethnic business. Often diasporans act as third-party mediators connecting organizations and information sources, thus firms can also benefit from being brokered by immigrants due to the co-nationality and solidarity effect, which influences the relationship quality (Hernandez, 2014). Diasporans are active in several dimensions, such as management, entrepreneurship, and investing, and have context-specific activity-related roles and drivers that influence their way of doing business. For example, Schotter and Abdelzaher (2013) studied how the Muslim diaspora influenced the internationalization process of firms from the Organization of Islamic Conference Countries. They analyzed the effect of boundary spanning that allowed the companies to connect internationally more efficiently as they employed particular trust elements and profited from the beneficial involvement of Muslim diaspora identity. National culture and the diaspora networks influence the entrepreneurship of diasporans, as Chand and Ghorbani (2011) illuminate in their comparative study on Indian and Chinese immigrants in the US, which points out culturespecific differences.

Many scholars and reports indicate the increased significance of diaspora business and related entrepreneurship, which refers to the continuation of the root cause, that is, the increasing flows of migration (for 
example, Brinkerhoff, 2009; Hart, 2011). Ethnic businesses established by diasporans are part of their everyday life in receiving countries (for example, Brinkerhoff, 2009). However, the role of ethnic background is twofold: ethnicity often forms the underlying reason for the existence of the customer base or the product per se (Brinkerhoff, 2009), but there is also an increasing number of foreign-born entrepreneurs who move out of ethnic enclaves into the mainstream, globally connected economies of the countries of immigration, and from necessity entrepreneurship to opportunity entrepreneurship (Hart, 2011). In a similar vein, entrepreneurial activities may be triggered by numerous reasons, from necessity ('forced entrepreneurship') to opportunity development. In fact, four routes to entrepreneurship have been identified (Xavier et al., 2012). Homophily, trust, solidarity, altruism, patriotism, and cooperation are among the concepts that have been brought up as influence factors for generations of diaspora-related business (for example, Gillespie and McBride, 2013; Hernandez, 2014; Javorcik et al., 2006), while there is still discussion on the applicability of these factors in dissimilar contexts (Gillespie and McBride, 2013).

Owing to the variations in the definitions of diaspora, there are also many foci with differing objects of research in the entrepreneurship research on migrants and diaspora. Immigrant entrepreneurship is an important socio-economic phenomenon with implications for regional and economic development (Aliaga-Isla and Rialp, 2013). Similarly, diasporans as international entrepreneurs have been identified as significant factors for economic activity and development in the developing country context (Nkongolo-Bakenda and Chrysostome, 2013), but their effect is not confined to one country setting. Riddle et al. (2010) define transnational diasporan entrepreneurs as migrants, and their descendants, who establish entrepreneurial activities that span the national business environments of their countries of origin and countries of residence.

Carbonell et al. (2011) offered variables that characterize entrepreneurs and explain attitudes and the success or failure of enterprises: personal traits, motivation and intentions, education, and environment. They discuss the concepts of immigrant entrepreneur and ethnic entrepreneur and point out significant ontological differences. They refer to the terms immigrant, minority, and ethnic as elements of identification, and denote that the immigrant entrepreneur term does not apply for the second or third generations. They find the term 'ethnic entrepreneur' to represent wider perspectives and to refer to both the immigrant population that set up a business and those people who belong to ethnic minorities even when they are not immigrants. Zhou (2004) also provides a review for the conceptual advancement regarding ethnicity and entrepreneurship. 
Therefore, to include the subsequent generation, which may well represent the diaspora's international connectivity and effects, the term 'diaspora entrepreneurship' is more suitable for the concept of 'permanent' entrepreneurial activities.

The cultural approach toward entrepreneurship focuses on the type of resources that stem from the entrepreneur's ethnic group and origin. Carbonell et al. (2011) talk about 'ethnic resources' and refer to all the socio-cultural factors that entrepreneurs use to set up and develop their businesses from which they benefit actively or passively, which is in line with the tangible (financing) and intangible (information, advice, guidance) resources identified by Light and Gold (2000). The contextual approach focuses on the socio-economic context of the country of residence and its favorable aspects regarding business activity.

Xavier et al. (2012) introduce various paths to the entrepreneurship of migrants and note the importance of the push factor of obstacles in the host labor market, which Light and Gold (2000) consider as an explanatory factor for entrepreneurship. Carbonell et al. (2011) highlight poverty, unemployment, workplace discrimination, language barriers, and low salaries as push factors and drivers for entrepreneurship, and claim livelihood seeking to be the main motivation. Interestingly, these push factors that are identified for immigrant, ethnic, and diaspora entrepreneurs are very similar to the push factors that have stimulated the migration in the first place. On the other hand, the integration approach that combines both cultural and contextual-structural approaches incorporates the elements of opportunities and opportunity structures and embeddedness, which have been lacking in most previous research. Thus, the pull forces influence the entrepreneurial activities parallel to push forces. Aliaga-Isla and Rialp (2013) systematically reviewed the literature on immigrant entrepreneurship and suggested that there is a need for further research in understanding how immigrants identify entrepreneurial opportunities in their host country. They also appeal for more meso- and macro-level analyses that include the institutional context, which plays a relevant role in immigrant entrepreneurship.

\subsection{Diaspora and Its Roles in Economic Development, FDI, and DDI}

Remittances are central in diaspora research. Diaspora networks generate immense capital flows. In 2010, worldwide remittance flows were estimated to have exceeded $\$ 440$ billion (Dutia, 2012). As Usher (2005) notes, other effects through engagement are more complicated in their nature, such as FDI. In diaspora research, the notion of DDI is emerging, which describes the character of this investment better than the 
classic notion of FDI as it incorporates the diasporans. Soft aspects related to respective diaspora networks, such as global learning and knowledge transfer, have provided interesting research findings as there are particular mechanisms for industry-specific spillovers that influence economic development through location choice (Hernandez, 2014). Dutia's (2012) study supports the importance of mechanisms and adds the dimension of diaspora networks as vital for respective growth and development. Vaaler (2013) studied remittances related to home country venture funding and found that diasporans enhance home country venture funding access. In addition, he also points out that diaspora concentration abroad facilitates more effective discovery of $\mathrm{COO}$ venture opportunities.

Diaspora has a strong connection to economic development and the global economy (for example, Bergsten and Choi, 2003; Cohen, 2008). Cohen (2008) criticizes the late discovery of diasporas as agents of development by rich countries and pinpoints how diasporas actively contribute to the economic development of the country of origin and reduce poverty. He explicates the effect with a British diaspora study, which demonstrates that development agencies should (1) secure the rights of migrants, (2) cut the cost of money transfers, (3) encourage migrants to invest in community initiatives in their home countries, and (4) engage with pro-poor drivers of change at home (Cohen, 2008, p. 168). Remittances are increasing; international migrants from developing countries are expected to send $\$ 436$ billion in remittances to their home countries in 2014, which indicates a growth of 7.8 percent throughout 2013. Global remittance flows, including those to high-income countries, were estimated at $\$ 542$ billion in 2013 (http://econ.worldbank.org, accessed 25 April 2014). Remittances create a financial flow that is larger than FDI flows (Cohen, 2008, p. 168), and the amount sent to developing countries is three times the size of the official aid (http://econ.worldbank.org, accessed 25 April 2014). The World Bank considers diasporas as an important source of trade, capital, technology, and knowledge for countries of origin and destination. China and India are good examples of $\mathrm{COO}$ benefits, while Israel, Ireland, and Italy have particularly benefitted from diaspora investment and entrepreneurship (Kotabe et al., 2013). Rauch and Trindade (2002) examine the role of ethnic Chinese networks in international trade facilitation and provide evidence for their effects.

Flisi and Murat (2011, p. 803) provide an important contribution to the discussion on efficient economic outcomes and diaspora linkages, stating that the ineffectiveness of the links immigrant communities potentially provide may signal situations of missed economic opportunities. They suggest that policies aiming at the undifferentiated restraint of migration 
inflows can be myopic in not contemplating the gains that immigrant networks can bring to the economy.

Diasporas invest in various constellations, inward and outward. They are not only active as entrepreneurs in their COR, but also as foreign direct investors from abroad to $\mathrm{COO}$, although this foreignness is somewhat questioned. Remittances are only one source of capital. The patriotic and altruistic notion of diaspora investment behavior often appears in research assumptions instead of profit and dividends. Ethnic advantage, altruism, homeland orientation, and perceptions of business impediments are discussed in the context of diaspora interest in homeland investment (Gillespie et al., 1999). Informal barriers, such as social, cultural, and institutional differences, have significant negative effects on economic exchange and transactions (Obstfeld and Rogoff, 2000). Flisi and Murat (2011) consider migrant communities to be a counteractive force that tends to lower these invisible barriers since they build links between their origin and host countries. Foreign direct investments as operations of high complexity, cost, and risk are influenced by larger informational asymmetries. Hence, Flisi and Murat (2011) claim that higher skills and educational attainment are required for FDI, and they introduce the issue of exogeneity (ibid., p. 797). They discuss the analytical concepts, in particular, the impact of educational attainment and income level both in the country of origin and in the host country. Among others, Javorcik et al.'s (2006) research supports the importance of high skills and educational attainment for investments. However, Flisi and Murat's (2011) study confirms the FDI-related importance of high skills for the UK, Germany, and France, but in Italy and Spain, the FDI model was affected by past mass emigration rather than high skills. Gao et al. (2013) also provide evidence that outward FDI is positively affected by diaspora. Their findings show that the two-way mobility of highly skilled Chinese students and scholars significantly promotes Chinese outward FDI.

The models of FDI are divided as vertical or horizontal: firms invest horizontally to sell abroad the same goods that are sold at home, and make vertical investments to exploit relative factor endowment differences. Flisi and Murat (2011, p. 798) build on the assumption that horizontal FDI takes place between similar countries, while the opposite is valid for vertical FDI, but their study shows the absence of a homogenous pattern. In addition, they also found country-related differences in FDI behavior stemming from distance, common language, and colonial history (ibid., p. 803).

It is notable that diaspora FDI is not exclusively directed to the homeland (that is, country of origin) (see Gao et al., 2013), despite the fact that diasporans have particular advantages related to their homeland business 
that others do not have (Gillespie et al., 1999). In particular, circularity and multidirectional mobility create development potential for FDI.

Diaspora direct investment, where migrants return to their home society to establish businesses, is recognized as an important development tool, but it may also benefit the country of residence. Debass and Ardovino (2009) perceive a new paradigm shift as DDI has emerged and improved upon traditional FDI even during a major economic downturn. Thus, the roles and dynamics of DDI differ from FDI. Diaspora direct investment is also referred to as investments of the 'returnees'. Diaspora direct investment involves five roles: the brain-gainer, the technologist, the brave capital investor, the catalyst, and the diplomat (Debass and Ardovino, 2009). These roles illustrate the various dimensions of motivations that are specific to DDI and constitute relational, emotional, patriotic, and altruistic motivations that are not present in FDI (see Brinkerhoff, 2009; Elo and Jokela, 2014). Therefore, it becomes clear that the ontological assumptions related to FDI and DDI differ, but this categorization does not mean that diasporans are limited to act within DDI schema.

\subsection{Synthesis}

The diaspora landscape is in flux. Diaspora flows have evolved beyond the classical poor-to-rich diaspora. At the same time, sending- and receivingcountry situations have changed character and novel types of diaspora, including pull and push forces, have emerged. Temporal orientations of diaspora are complemented with temporary and circular variations, in addition to traditional permanent migration.

Thus, 'transferrable brain' resources in the form of brain drain and gain have been complemented with brain circulation, that is, triangular human talent flow (Tung, 2008) referring to novel boundary-less careers, cosmopolitanism, and advances of globalization. Labor diasporas influence economic development and business in multiple ways, but there are fundamental differences in various cohorts of diaspora and the more researched high-skilled diaspora illustrates numerous benefits for $\mathrm{COO}$ and COR as well as firm/entrepreneurial performance. Clusters aggregate resources and are facilitated by diaspora; however, diasporas tend to emerge in metropolitan areas and where accumulation of migrants takes place.

Diaspora knowledge is crystallized in the concepts of immigrant effect (Chung and Tung, 2013), social capital and social networks (for example, Hernandez, 2014), ethnic heritage and knowledge transfer (for example, Scheffran et al., 2012). However, diasporas are not only actors, but also target customers with their knowledge and social networks, as Kumar and Steenkamp (2013) note, especially for emerging-market companies to tap. 
Diaspora identity is in a state of flux (Hannerz, 1997). Diasporans behave differently according to constellations of identity, as diasporas are not homogenous. Diasporas act in multifaceted 'spaces' and have transnational characteristics (see Hannerz, 1997; Levitt, 2001; Vertovec, 1999, 2004) that reach beyond the nation state (Tölölyan, 1996). Thus, diasporans have particular cross-cultural competences.

Diasporans facilitate international trade and act as conduits in business (for example, Riddle et al., 2010; Schotter and Abdelzaher, 2012). Many diasporans are driven by necessity to become entrepreneurs (see Carbonell et al., 2011; Metzger, 2014; Xavier et al., 2012), but diaspora entrepreneurs and their businesses are also influenced by aspects such as homophily, trust, solidarity, altruism, patriotism, and cooperation. They also generate ethnic businesses and develop their countries of origin (for example, Nkongolo-Bakenda and Chrysostome, 2013), for example, with investments and remittances (Dutia, 2012; Vaaler, 2013).

\section{DEVELOPMENT OF DIASPORA RESEARCH IN INTERNATIONAL BUSINESS AND ECONOMY: FINDINGS OF THE REVIEW}

What kinds of research findings have been discovered so far? There is an emerging body of research on diaspora issues related to IB and the economy. The multifaceted research literature applies many different perspectives from macro- to micro-level. In addition, the research mainly occurs within disciplinary boundaries, which creates limitations for comparisons and cross-examination. In the process of searching for key issues researched so far, certain areas of study were clearly more visible and present. However, as objects of the study, there were only very few articles focusing on 'diaspora networks' (see Dutia, 2012; Kuznetsov, 2006). Interestingly, the dimension and concept of diaspora network was strongly present in the majority of the studies more implicitly than explicitly. The findings illustrate that most researched areas relate to flows and circulation of brain and skills, diaspora-related entrepreneurship and diaspora investment behavior, and economic development of COO. On the other hand, the particularities of resources and knowledge transfer and the roles of identity and diaspora networks are more seldom the object of research. In general, the studies have not yet explored the full range of effects and functions related to diaspora networks, and thus provide a rather puzzlelike picture of the phenomenon.

What are the influences of diaspora and the resulting diaspora networks in the globalized economy? Diasporas interconnect the world and mobilize 
social capital. Diaspora can benefit COO, COR, and previous CORs in the case of circulating migration, but temporary diaspora also have positive influences. Diasporas may also have negative influences if employed in transnational organized crime. Diasporas influences the competitiveness of a nation, its development and international trade, capital inflow, innovation and technology (Chand, 2010). Diasporas not only transfer knowledge and provide particular abilities and skills, but they also provide labor and consumers. Diasporas create ethnic markets and foster clusters. Patriotic or altruistic diaspora decision-making facilitates COO development and diaspora may influence the society through its different social cohesiveness. Diasporas share transnational characteristics, but are influenced by the COO-related emotions. Diasporans facilitate trust and international trade, and they are more active in entrepreneurship. Diasporas develop markets by starting businesses in COR and in $\mathrm{COO}$ by investing or repatriating.

What forms do diasporas take? Are there particular mechanisms identified in the extant research? Network structure and mechanisms of diaspora have received substantial research interest, especially in sociological studies. Diaspora consists of individuals, but also of their networks and societies of belonging. Individuals form social formations, such as diaspora networks. Therefore, diasporans are connected to multiple networks: COO networks, COR networks, and other diaspora networks. The multiplicity of diaspora network dimensions extends beyond dyadic transnationalism. Individual diasporans are influenced by their diaspora networks via socio-cultural bonds, but also via home and host country stimuli. Diaspora networks form actors that possess both societal and business-related agency. Interestingly, the intra- and inter-diaspora effects seemed to be strong in entrepreneurial activities and other social aspects, especially related to low-skilled diaspora, while they were not that strongly emphasized in the case of highly skilled diaspora. Highly skilled diaspora seemed to be examined more in the context of diaspora and external environment and as individuals. The findings illustrate that especially high-skilled diasporans (also referred to as 'talent') improve performance, boost internationalization, innovate and disseminate innovation, and act as business conduits. Diaspora networks are a crucial tool to employ when diasporas interconnect markets and businesses. The respective resources and social capital are shared and employed. The mechanisms on the systemic level - such as migration flows, brain circulation, remittances, trade flows, and diffusion of innovation - have been discovered in many studies. In contrast, the mechanisms on entrepreneurial and business activities, as well as knowledge transfer, are only partially understood. 


\subsection{Research Aspects of the Diaspora Networks Literature}

The major aspects found in diaspora network research relate to time, theoretical lenses, foci, and disciplinary limitations. Economic development, emerging economies, and entrepreneurial issues are among the key aspects that drove research attention. Diaspora research in IB has been rather nominal in volume, but has increased since 2011, stimulated by the Twelfth Annual International Business Research Forum (2011) in the US, especially with the special issue of the International Business Review (2011) on 'International ethnic entrepreneurship' by Çavusgil et al., and the special issue of the Journal of International Management (in 2013) 'Diaspora investment and entrepreneurship: the role of people, their movements, and capital in the international economy' by Kotabe et al., and the numerous publications resulting from the 2012 conference of the Academy of International Business on 'Rethinking the roles of business, government and NGOs in the global economy' in Washington, DC. However, the issue of terminology influences the identification of research papers, as most articles are not directly identifiable with the term 'diaspora', but its variants. On the other hand, there is a considerable amount of literature that employs the term 'diaspora', for example, that published by Riddle and Brinkerhoff. Regardless of terminology discussions, the implications of migration and globalization on the real world of IB, the invisible influence mechanisms of diaspora, and the establishment of emerging economy multinational research have stimulated research interest on novel topics, such as affect (see Barnard and Pendock, 2013) and business incubators (Riddle et al., 2010) in diaspora. At the same time, the field of international entrepreneurship is supplemented in its scope by variations more toward diaspora and immigrant entrepreneurs (for example, Aliaga-Isla and Rialp, 2013). Thus, there is a considerable amount of literature related to, but not focusing on, the phenomenon of diaspora networks in IB. This review only covers a small selection of relevant articles, books, and reports.

The theory development has been enriched with various approaches from systemic and national competitiveness views (for example, Chand, 2010; de Lange, 2013) to the reverse side of the negative counterfeit business (Gillespie and McBride, 2013) and further to individual level virtuous circle dynamics (Kuznetsov, 2008) and investment motivations (for example, Gillespie et al., 1999). Overall, the scope of the theories is broadening. The classic diaspora research on flows of remittances, immigration and resource flows, and investment behavior has recently been accompanied by articles focusing on non-economic aspects, such as social effects, knowledge transfer, language and family, among others. The body 
of knowledge may still be rather fragmented in terms of the IB perspective, but the overall research discussion has rapidly progressed.

The level of analysis illustrates a wide spectrum of alternatives; not only are articles on macro-economic aspects central to progress, but equally central are articles having an individual, even mille-micro view (see Vissak and Zhang, 2014). Meso-level foci are often in the contextual setting as industry development and clusters provide a fruitful frame for analysis (for example, Sonderegger and Täube, 2010; Talib et al., 2012).

The dominant perspective on diaspora being a developing country syndrome, a flow between weaker and stronger countries, has turned around, especially concerning the emerging market MNCs, China and India. The direction of flows has become more two-way and the content of the flows has rapidly evolved (for example, Bolt, 1997; Newland and Tanaka, 2010). The applied methodologies vary significantly, but many journal articles are still based on statistical analysis of secondary data. There is very little descriptive or narrative style research (see Elo and Jokela, 2014).

There are still many aspects that remain unexplored in the current research literature, such as motivation, communication, marketing, organization, and management analyses of diaspora networks. However, beyond academic journals, there is a large body of knowledge, data, and other information that stems from publishers such as the European Union (EU), the World Bank, the OECD, the Migration Policy Institute, and various national-level institutions. These publications provide information on specific aspects and enrich the extant research.

\section{DISCUSSION AND CONCLUSION}

The key aspects identified in this review illustrate that the effects generated by diaspora networks on IB and the economy are complex and often invisible. Despite these effects, their inherent role, and explanatory power, diaspora networks are not included in most IB theories. The review clearly indicates that the diaspora phenomenon, especially diaspora networks in IB, includes resources and risks that require further research attention. It presents numerous challenges. First, diaspora networks require substantial empirical research as increases in migration result in new forms of diasporic life and business that will shape IB and the economy. There is a need for more theoretical discussion that unifies fragmented aspects and enhances the development of research. This discussion should be also supported by empirical research.

Second, diaspora presents a challenge for governments: how to manage mobility with optimal multidirectional benefits, how to tackle the multiple 
identity and citizenship issues, and how to govern diversity positively to maximize positive diaspora engagement in $\mathrm{COO}$ and COR (see Usher, 2005). Implications on policy making refer to the different kinds of support that diaspora businesses require in their transnational contexts and activities. There are institutional issues in IB and entrepreneurship that require further research, so that positive diaspora business can be better enabled. The fact is that the diaspora resources exist and in many cases they remain under-exploited and provide suitable potential for illegal activities, and crime as a livelihood in the labor and business markets fails. The necessity and affect aspects involve securitization and shadow economy aspects (see Barnard and Pendock, 2013; Dugan and Edelstein, 2013; Gillespie and McBride, 2013; Xavier et al., 2012), which require additional research.

Third, as diaspora related theories evolve, the theoretical and methodological implications change. For example, the underlying dichotomy between sending and receiving has led to a research bias in analyzing the phenomenon, but circularity research has pointed out that this 'black-andwhite' explanatory schema is no longer valid. On the other hand, studies on emerging market diasporans pinpoint the multiplicity of options that diasporans have and that they may act as investors in FDI and DDI, investors in their host countries, and in third countries as well. Thus, diaspora behavior in business is not homogeneous or unidirectional; diaspora investments are not limited to DDI or exhaustively explained by any particular category. Hence, theoretical perspectives have evolved rapidly. Diaspora research has explored and explained numerous aspects that have concerned IB researchers, such as reverse FDI, resource flows and their drivers, social mechanisms, multicultural capabilities, learning and creativity, among others. The contributions of diaspora take place on multiple levels, from macro-level flows of resources to mille-micro level bridging effects. Diaspora research has provided a large body of knowledge on development, when analyzing developing and emerging country phenomena in relation to developed countries. Geographically, the spectrum of countries and regions also includes unusual states and combinations, from Nepal to the US. Culturally, these studies provide novel and useful understandings of aspects that economics leaves uncovered. Many studies are able to explain and describe processes and partial dynamics of IB phenomena, but future research should enrich the research literature with empirical and qualitative studies. For example, entrepreneurship is a tremendously significant channel for prosperity and employment, and diaspora entrepreneurship research explores novel dynamics and drivers that benefit societal development and IB. Further studies exploring success and failure factors, incubator effects, and influence of institutional support are required. 
In addition, the methods and research approaches chosen need to be carefully designed to avoid various inherent bias. A large part of the extant research is based on secondary data and the proportion of receiving country perspective is rather dominant. In-depth qualitative studies, longitudinal studies and cross-national comparisons are very rare. Hence, more plurality in methodological approaches could potentially facilitate the progress of diaspora research.

Finally, there are remarkable managerial implications for IB. Managers responsible for sales and marketing, sourcing, international service networks, and international expansion strategies should identify and assess the potential of diaspora networks that the firm may employ. Recruitment should consider transnational diasporans when particular international abilities for difficult markets are required. In addition, innovation and research and development management can benefit from diasporans and their networks.

\section{REFERENCES}

Aliaga-Isla, R. and A. Rialp (2012), 'How do information and experience play a role in the discovery of entrepreneurial opportunities? The case of Latin-American immigrants in Barcelona', Latin American Business Review, 13 (1), 59-80.

Aliaga-Isla, R. and A. Rialp (2013), 'Systematic review of immigrant entrepreneurship literature: previous findings and ways forward', Entrepreneurship \& Regional Development, 25 (9-10), 819-44.

Barnard, H. and C. Pendock (2013), 'To share or not to share: the role of affect in knowledge sharing by individuals in a diaspora', Journal of International Management, 19 (1), $47-65$.

Bergsten, C.F. and I. Choi (2003), 'The Korean diaspora in the world economy', Special Report 15, January, Institute for International Economics, Washington, DC.

Bevelander, P. and N. Irastorza (2014), 'Economic integration of intermarried labour migrants, refugees and family migrants to Sweden: premium or selection?', Discussion Paper Series, IZA DP No.8065, March, Institute for the Study of Labor, Bonn.

Bolt, P. (1997), 'Chinese diaspora entrepreneurship, development, and the world capitalist system', Diaspora: A Journal of Transnational Studies, 6 (2), 215-35.

Brinkerhoff, J.M. (2006), 'Diasporas, skills transfer, and remittances: evolving perceptions and potential', in C. Wescott and J.M. Brinkerhoff (eds), Converting Migration Drains into Gains: Harnessing the Resources of Overseas Professionals, Manila: Asian Development Bank, pp. 1-32.

Brinkerhoff, J.M. (2009), Digital Diasporas: Identity and Transnational Engagement, Cambridge: Cambridge University Press.

Carbonell, J.R., J.C.P. Hernandez and F.J.L. Carcía (2011), 'Business creation by immigrant entrepreneurs in the Valencian community: the influence of education', International Entrepreneurship Management Journal, 10 (2), 409-26.

Carr, S.C., K. Inkson and K. Thorn (2005), 'From global careers to talent flow: reinterpreting "brain drain", Journal of World Business, 40 (4), 386-98.

Çavuşgil, T., D.Z. Nayir, G.M. Hellstern, T. Dalgic and E. Çavuşgil (2011), 'International ethnic entrepreneurship', International Business Review, 20 (6), 591-2.

Chand, M. (2010), 'Diasporas as drivers of national competitiveness', in T. Devinney, 
T. Pedersen and L. Tihany (eds), Advances in International Management, vol. 23, Bingley: Emerald, pp. 583-602.

Chand, M. and M. Ghorbani (2011), 'National culture, networks and ethnic entrepreneurship: a comparison of the Indian and Chinese immigrants in the US', International Business Review, 20 (6), 593-606.

Chung, H.F. and R.L. Tung (2013), 'Immigrant social networks and foreign entry: Australia and New Zealand firms in the European Union and Greater China', International Business Review, 22 (1), 18-31.

Cohen, R. (1997), 'Diasporas, the nation-state and globalisation', in: G. Wang (ed.), Global History and Migrations, Global History, vol. 2, Boulder, CO: Westview Press, pp. 117-43.

Cohen, R. (2008), Global Diasporas: An Introduction, 2nd edn, London and New York: Routledge.

Cucinotta, A. (2010), 'Counterfeit products in international business', International Business, Vaasa: Vaasan Ammattikorkeakoulu.

De Lange, D.E. (2013), 'Embedded diasporas: shaping the geopolitical landscape', Journal of International Management, 19 (1), 14-25.

Debass, T. and M. Ardovino (2009), Diaspora Direct Investment (DDI): The Untapped Resource for Development, Washington, DC: United States Agency for International Development.

Dugan, M. and A. Edelstein (eds) (2013), Migration Matters, Oxford: Inter-Disciplinary Press.

Dutia, S.G. (2012), 'Diaspora networks: a new impetus to drive entrepreneurship', Innovations, 7 (1), 3-11.

Easterby-Smith, M., R. Thorpe and A. Lowe (2002), Management Research: An Introduction, London: Sage Publications.

Elo, M. and P. Jokela (2014), 'Social ties, Bukharian Jewish diaspora and entrepreneurship: narratives from entrepreneurs', in C. Rapoo, M.L. Coelho and Z. Sarwar (eds), New Perspectives in Diaspora Experience, Oxford: Inter-Disciplinary Press.

Flisi, S. and M. Murat (2011), 'The hub continent. Immigrant networks, emigrant diasporas and FDI', The Journal of Socio-Economics, 40 (6), 796-805.

Ford, D. (ed.) (2002), Understanding Business Marketing and Purchasing, 3rd edn, London: Thomson Learning.

Gao, L., X. Liu and H. Zou (2013), 'The role of human mobility in promoting Chinese outward FDI: a neglected factor?', International Business Review, 22 (2), 437-49.

Gillespie, K., L. Riddle, E. Sayre and D. Sturges (1999), 'Diaspora interest in homeland investment', Journal of International Business Studies, 30 (3), 623-34.

Gillespie, K. and J.B. McBride (2013), 'Counterfeit smuggling: rethinking paradigms of diaspora investment and trade facilitation', Journal of International Management, 19 (1), 66-81.

Hall, S. (1990), 'Cultural identity and diaspora', in J. Rutherford (ed.), Identity: Community, Culture, Difference, London: Lawrence and Wishart, pp. 222-37.

Hannerz, U. (1997), 'Borders', International Social Science Journal, 49 (154), 537-48.

Harikkala, R. (2013), 'An interaction framework for deploying the knowledge of diasporas: using Finland as an example', master's thesis, Turku School of Economics, Turku.

Hart, D.M. (2011), 'Founder nativity, founding team formation, and firm performance in the US high-tech sector', International Entrepreneurship and Management Journal, 10 (1), $1-22$.

Hart, D.M. and Z.J. Acs (2011), 'High-tech immigrant entrepreneurship in the United States', Economic Development Quarterly, 25 (2), 116-29.

Hepp, A., C. Bozdag and L. Suna (2011), Mediale Migranten, Mediatisierung und die kommunikative Vernetzung der Diaspora. Wiesbaden: Verlag für Sozialwissenschaften, pp. 239-52.

Hernandez, E. (2014), 'Finding a home away from home: effects of immigrants on firms' foreign location choice and performance', Administrative Science Quarterly, 59 (1), 73-108.

Javorcik, B.S., C. Oezden, M. Spatareanu and C. Neagu (2006), 'Migrant networks and foreign direct investment', Policy Research Working Paper 4046, World Bank. 
Kotabe, M., L. Riddle, P. Sonderegger and F. Täube (2013), 'Diaspora investment and entrepreneurship: the role of people, their movements, and capital in the international economy', Journal of International Management, 19 (1), 3-5.

Kumar, N. and J.B.E. Steenkamp (2013), 'Diaspora marketing', Harvard Business Review, $91(10), 127-50$

Kuznetsov, Y. (ed.) (2006), 'Diaspora networks and the international migration of skills: how countries can draw on their talent abroad', WBI Development Studies, 30 May, World Bank.

Kuznetsov, Y. (2008), "Mobilizing intellectual capital of diasporas: from first movers to a virtuous cycle', Journal of Intellectual Capital, 9 (2), 264-82.

Leinonen, J. (2012), "Money is not everything and that's the bottom line": family ties in transatlantic elite migrations', Social Science History, 36 (2), 243-68.

Levitt, P. (2001), 'Transnational migration: taking stock and future directions', Global Networks, 1 (3), 195-216.

Lewin, A.Y. and X. Zhong (2013), 'The evolving diaspora of talent: a perspective on trends and implications for sourcing science and engineering work', Journal of International Management, 19 (1), 6-13.

Light, I.H. and S.J. Gold (2000), Ethnic Economies, San Diego, CA: Academic Press.

Lumpkin, G.T. and G.G. Dess (2001), 'Linking two dimensions of entrepreneurial orientation to firm performance: the moderating role of environment and industry life cycle', Journal of Business Venturing, 16 (5), 429-51.

Malhotra, N.K., J. Agarwal and M. Peterson (1996), 'Methodological issues in cross-cultural marketing research: a state-of-the-art review', International Marketing Review, 13 (5), $7-43$.

McLaughlin, S., R. Muenz, R. Buente, G. Hultin, W. Mueller and R. Skeldon (2011), 'Temporary and circular migration: opportunities and challenges', Working Paper no. 35, European Migration and Diversity, Europe's Political Economy Programmes, European Policy Centre.

Metzger, G. (2014), 'Existenzgruendungen durch Migranten: Gruendungslust belebt das Geschehen', KFW Economic Research, 67, 1-4.

Muzychenko, O. (2008), 'Cross-cultural entrepreneurial competence in identifying international business opportunities', European Management Journal, 26 (6), 366-77.

Newland, K. and H. Tanaka (2010), Mobilizing Diaspora Entrepreneurship for Development, Washington, DC: Migration Policy Institute.

Nkongolo-Bakenda, J.M. and E.V. Chrysostome (2013), 'Engaging diasporas as international entrepreneurs in developing countries: In search of determinants', Journal of International Entrepreneurship, 11 (1), 30-64.

Obstfeld, M. and K. Rogoff (2000), 'The six major puzzles in international macroeconomics: is there a common cause?', in B. Bernanke and K. Rogoff (eds), NBER Macroeconomics Annual 2000, vol. 15, Cambridge, MA: MIT Press.

Oliveri, F. (2013), 'Towards a global citizenship from below: migrant farmworkers' strike in Nardò, Southern Italy', in M. Dugan and A. Edelstein (eds), Migration Matters, Oxford: Inter-Disciplinary Press, pp. 47-62.

Organisation for Economic Co-operation and Development (OECD) (2009), International Migration Outlook 2009, OECD Publishing.

Organisation for Economic Co-operation and Development (OECD) (2013), 'Trends in migration', in OECD Factbook 2013: Economic, Environmental and Social Statistics, OECD Publishing, dx.doi.org/10.1787/factbook-2013-7-en.

Organisation for Economic Co-operation and Development (OECD) (2014), 'Migration', in Society at a Glance 2014: OECD Social Indicators, OECD Publishing, dx.doi.org/10.1787/ soc_glance-2014-9-en.

Rauch, J.E. and V. Trindade (2002), 'Ethnic Chinese networks in international trade', Review of Economics and Statistics, 84 (1), 116-30.

Riddle, L. and J. Brinkerhoff (2011), 'Diaspora entrepreneurs as institutional change agents: the case of Thamel.com', International Business Review, 20 (6), 670-80. 
Riddle, L., G.A. Hrivnak and T.M. Nielsen (2010), 'Transnational diaspora entrepreneurship in emerging markets: bridging institutional divides', Journal of International Management, 16 (4), 398-411.

Safran, W. (1991), 'Diasporas in modern societies: myths of homeland and return', Diaspora: A Journal of Transnational Studies, 1 (1), 83-99.

Scheffran, J., E. Marmer and P. Sow (2012), 'Migration as a contribution to resilience and innovation in climate adaptation: social networks and co-development in Northwest Africa', Applied Geography, 33 (April), 119-27.

Schotter, A. and D. Abdelzaher (2013), 'The boundary spanning effects of the Muslim diaspora on the internationalization processes of firms from organization of Islamic conference countries', Journal of International Management, 19 (1), 82-98.

Sheffer, G. (ed.) (1986), Modern Diasporas in International Politics, London and Sydney: Croom Helm.

Sonderegger, P. and F. Täube (2010), 'Cluster life cycle and diaspora effects: evidence from the Indian IT cluster in Bangalore', Journal of International Management, 16 (4), 383-97.

Srivastava, S.K. (2007), 'Green supply-chain management: a state-of-the-art literature review', International Journal of Management Reviews, 9 (1), 53-80.

Talib, N.A., S. Saudah Sofian, N.A. Mohamad, A.A. Senin, H.A. Kadir, H.M. Yusof and I. Hassan (2012), 'Leveraging Malaysian diaspora for cluster development initiatives', Business Strategy Series, 13 (5), 239-47.

Tölölyan, K. (1996), 'Rethinking diaspora(s): stateless power in the transnational moment', Diaspora: A Journal of Transnational Studies, 5 (1), 3-36.

Tung, R.L. (2008), 'Brain circulation, diaspora, and international competitiveness', European Management Journal, 26 (5), 298-304.

Usher, E. (2005), 'The evolving role of diasporas', Refugee Survey Quarterly, 24 (4), 47-9.

Vaaler, P.M. (2013), 'Diaspora concentration and the venture investment impact of remittances', Journal of International Management, 19 (1), 26-46.

Vertovec, S. (1999), 'Conceiving and researching transnationalism', Ethnic and Racial Studies, 22 (2), 447-62.

Vertovec, S. (2004), 'Migrant transnationalism and modes of transformation 1', International Migration Review, 38 (3), 970-1001.

Vissak, T. and X. Zhang (2014), 'Chinese immigrant entrepreneurs' involvement in internationalization and innovation: three Canadian cases', Journal of International Entrepreneurship, 12 (2), 1-19.

Waldinger, R. (1989), 'Immigration and urban change', Annual Review of Sociology, 15 (1), 211-232.

Wescott, C.G. and J.M. Brinkerhoff (eds) (2006), Converting Migration Drains into Gains: Harnessing the Resources of Overseas Professionals, Manila: Asian Development Bank.

World Bank (2006), accessed 20 August 2014 at http://web.worldbank.org/WBSITE/ EXTERNAL/WBI/WBIPROGRAMS/KFDLP/0, contentMDK:20946758 menuPK:172 7232 pagePK:64156158 piPK:64152884 theSitePK:461198,00.html.

Xavier, S.R., D. Kelly, J. Kew, M. Herrington and A. Vorderwülbecke (2012), 'Global entrepreneurship monitor 2012', Global Report, accessed 24 December 2014 at www.gemconsortium.org/docs/download/2645.

Zhou, M. (2004), 'Revisiting ethnic entrepreneurship: Convergencies, controversies, and conceptual advancements 1', International Migration Review, 38 (3), 1040-74. 